\title{
Evaluating pollution potential of leachate from landfill site, from the Pune metropolitan city and its impact on shallow basaltic aquifers
}

\author{
Sanjay S. Kale • Ajay K. Kadam • Suyash Kumar • \\ N. J. Pawar
}

Received: 29 October 2008 / Accepted: 27 January 2009 / Published online: 20 March 2009

(C) The Author(s) 2009. This article is published with open access at Springerlink.com

\begin{abstract}
Leachate produced by municipal solid waste dumping site near the metropolitan city of Pune, India was examined for its pollution potential and impact on surrounding shallow basaltic aquifers. Twenty-eight physico-chemical parameters during post- and pre-monsoon seasons (Nov 2006 and May 2007) were determined to assess the seasonal variation in the leachate pollution index (LPI) as well as in the groundwater quality. The leachate demonstrated higher LPI value during pre-monsoon, comparable to those at other metropolises outside India. Potentially toxic leachates derived from the dumping site have largely influenced the adjoining basaltic aquifers through two different modes of transport. Despite high contents of heavy metals $(\mathrm{Al}, \mathrm{Cd}, \mathrm{Cr}, \mathrm{Cu}$,
\end{abstract}

S. S. Kale · A. K. Kadam

Department of Environmental Sciences,

University of Pune, Pune 411 007, India

S. S. Kale

e-mail: sanjakale@gmail.com

A. K. Kadam

e-mail: kadamajaykumarl@gmail.com

S. Kumar · N. J. Pawar $(\varangle)$

Department of Geology, University of Pune,

Pune 411 007, India

e-mail: nipawar@unipune.ernet.in

S. Kumar

e-mail: suyashgwl@gmail.com
$\mathrm{Co}, \mathrm{Fe}, \mathrm{Mn}, \mathrm{Ni}, \mathrm{Pb}$ and $\mathrm{Zn}$ ) in the leachate, the aquifers in the close proximity of landfill site are least polluted by metallic contaminants possibly due to redox controls. Various geoenvironmental features governing the dispersal of leachate contaminants in the basaltic aquifers under semiarid climatic regime have been identified and discussed. Although a few remedial measures have been suggested to mitigate the impact of leachate percolation and dispersion, the present study demands for a proper solid waste management in metropolitan cities.

Keywords Leachate pollution index • Pune • Landfill $\cdot$ Basaltic aquifers

\section{Introduction}

Leachate is a polluted liquid emanating from the base of the landfill, which contains innumerable organic and inorganic compounds (Papadopoulou et al. 2007). The improper collection, segregation, and disposal practices of municipal solid waste (MSW) produce highly concentrated leachates. Dispersal of leachates poses potential threats to local ecosystems especially to soils and groundwaters (Jorstad et al. 2004). The composition of leachate depends upon the nature of solid waste buried, chemical and biochemical processes responsible for the decomposition of waste materials, and water content in total waste (Fatta et al. 1999; Mor et al. 2006). 
Leachates generated by the MSW in uncontrolled landfills have become a major environmental problem in million plus cities across the globe. Despite their hazardous impacts on environment, studies on the topic are sparse, particularly in hard rock landscapes. Groundwater contamination in hard rock terrains like basalts is an enduring situation because of the slow and unstable flow of water through constricted passages. There is a predominance of the slower rate of water flow and higher residence times. Moreover, the water migrates through the matrix of the host rock. This mechanism, in most of the cases, is good enough for restricting the passage of contaminants from source to receptors. On the contrary, the pollutants are released slowly toward the areas of the system with higher permeability, thereby creating constant level of contamination and maintaining their toxicities. The dispersion of pollutants in the surrounding aquifer media is therefore not gradual (with distance from source to receptors), inconsistent, and heterogeneous. This pronounces a demand for evolving a model to envisage the dominance of geoenvironmental features on the contaminant dispersal in hard rock backgrounds. For this intent, a MSW dumping site near Pune metropolitan city is selected with the objectives to (1) evaluate the leachate pollution potential, (2) examine geochemical status of groundwater in areas around the site, and (5) delineate the geoenvironmental features controlling groundwater pollution in a basaltic litho-environment.

\section{Background study}

Pune, in the western Indian state of Maharashtra, with an area of over $450 \mathrm{~km}^{2}$ and a vast population of 3.5 million, is a city still developing and expanding. According to the latest available estimates, it produces over 1,100 metric tons of municipal and post-consumer solid waste on a daily basis (ESR 2006). The exponential growth in the Pune metropolis during the last decade (in terms of area, industry, population, and living standards) has put immense pressures on solid waste management system of the local municipal body. As a common waste disposal practice in many metropolises (particularly in developing countries), trucks from different parts of Pune collect and bring solid wastes to the nearby site and unload in an irregular fashion. These wastes predominantly contain domestic wastes (household waste, street litter, municipal park sweeping waste, garden waste, commercial waste from shops and trading centers, kitchen wastes, etc.). Further wastes from poultry and fish markets, slaughterhouses, dairy farms, and non-infectious hospital waste are also dumped without proper segregation, except by the rag pickers who rummage through the garbage and partially segregate it. They generally collect glass material, plastics, and metals to sell them at recycling units.

The site under review was previously an abandoned stone quarry, which later (from 1993) served as a dumping site for MSW, with improper leachate collection system. Presently, it looks like a hillock (of $\sim 15-25 \mathrm{~m}$ height) with everincreasing heap of MSWs (Fig. 1a, b). The general composition of waste is as follows: organic matter, $65 \%$; paper, $8 \%$; plastic, rubber, leather, and synthetic $7 \%$; metal 6\%; inert matter $10 \%$; and glass 4\% (ESR 2006), out of which organic matter produces large amount of leachates. Consequently, the leachate production is high, organically complex in nature, and continuously growing. The instant effects of MSW decomposition are a foul and stinking smell felt from a distance and breeding of houseflies, vermin, and pathogens besides a very unpleasant sprawl. "Phursungi" and "Shewalewadi" are the two villages in this area severely affected due to leachate contamination in soil and groundwater. Unhygienic drinking water and garbage-induced diseases, like dysentery, cholera and hepatitis, are frequently reported in these villages during monsoon season. Therefore, the present work on the geochemistry of leachate as well as groundwaters from the study area was conducted.

\section{Study area}

Pune City restrains to the Deccan volcanic province (DVP) of Cretaceous-Eocene age (Krishnan 1982; Fig. 2). Despite the fact that cavities, vesicles, flow contacts, lava pipes, and tunnels can build up principal porosity in the basalt (Pawar and Shaikh 1995), the flows in the study area are relatively less porous. Conversely, 
Fig. 1 a MSW dumping site showing leachate pond, Pune, India. b MSW dumping site showing heap of solid waste, Pune, India
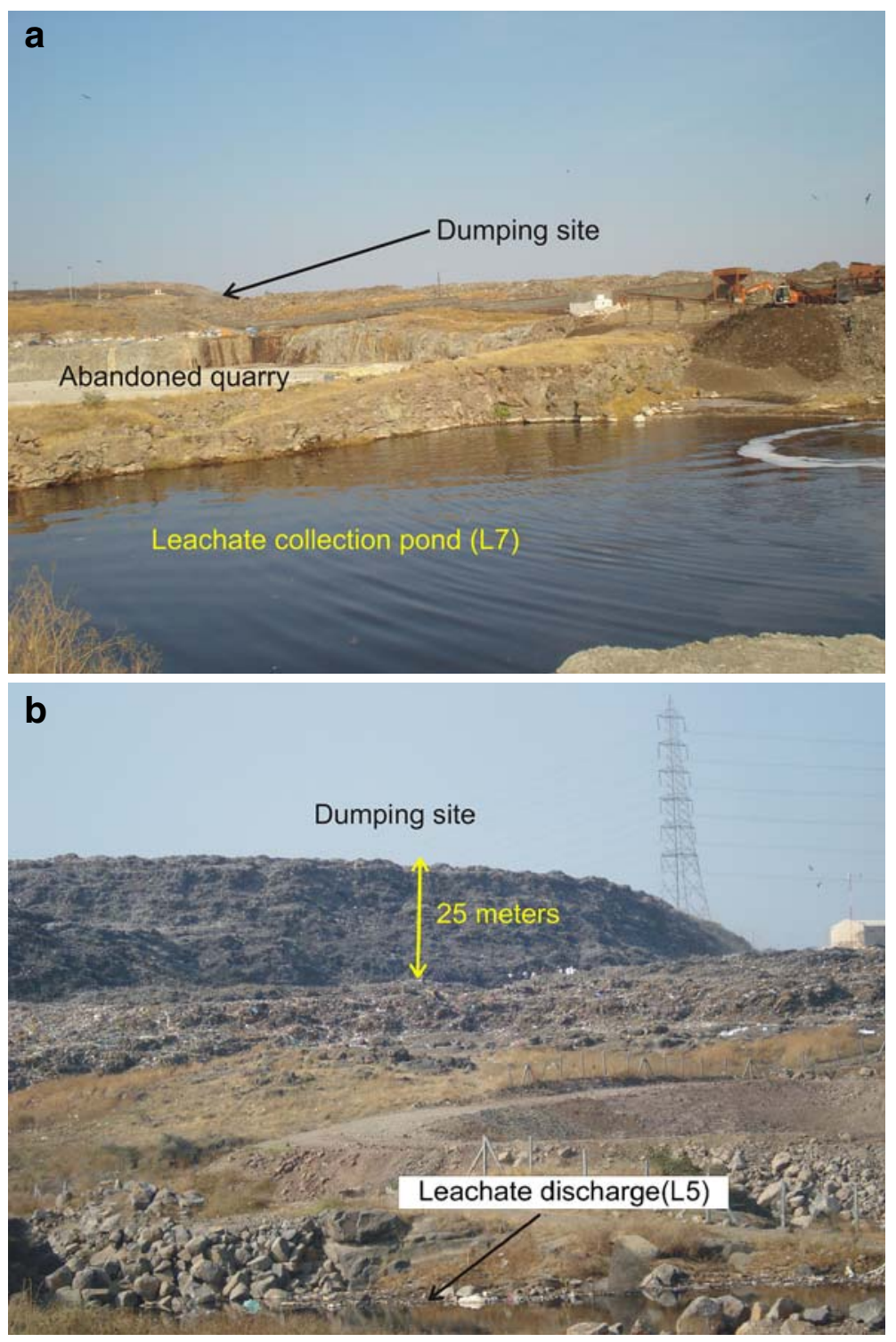

jointing and fracturing by way of interconnectivity have conveyed localized secondary porosity and permeability to form suitable groundwater reservoirs at places (Pawar et al. 2008). Furthermore, the cooling features such as columnar joints serve as hydrologic discontinuities, which in turn function as pathways for infiltration of rainwater. However, meager incidence of such primary openings in the exposed quarry sections nearby MSW site indicates low porosity and permeability to basaltic flows in the area. The studied dumping site is about $20 \mathrm{~km} \mathrm{SE}$ of Pune, on Pune-Saswad road (Fig. 3). The study area around the dumping site $\left(73^{\circ} 55^{\prime}\right.$ to $74^{\circ} 00^{\prime \prime} \mathrm{N}$ and $18^{\circ} 22^{\prime} 30^{\prime \prime}$ to $\left.\mathrm{E} 18^{\circ} 30^{\prime \prime}\right)$ is situated at elevation ranging between 550 and $660 \mathrm{~m}$ amsl with the MSW site located on the eastern slopes of a small topographic high. Climate in the area is semi-arid with an average annual rainfall of $550 \mathrm{~mm}$. The year 2006 experienced heavy rainfall (1266 mm; IMD 2007) much above the annual average of $550 \mathrm{~mm}$. June to September is the period of rainy season with occasional heavy rainfall events. This leads to dispersion of leachates in the surrounding lowlying areas. A small natural stream, namely, Kala Odha, further carries the leachates downstream 
Fig. 2 Location map of MSW dumping site

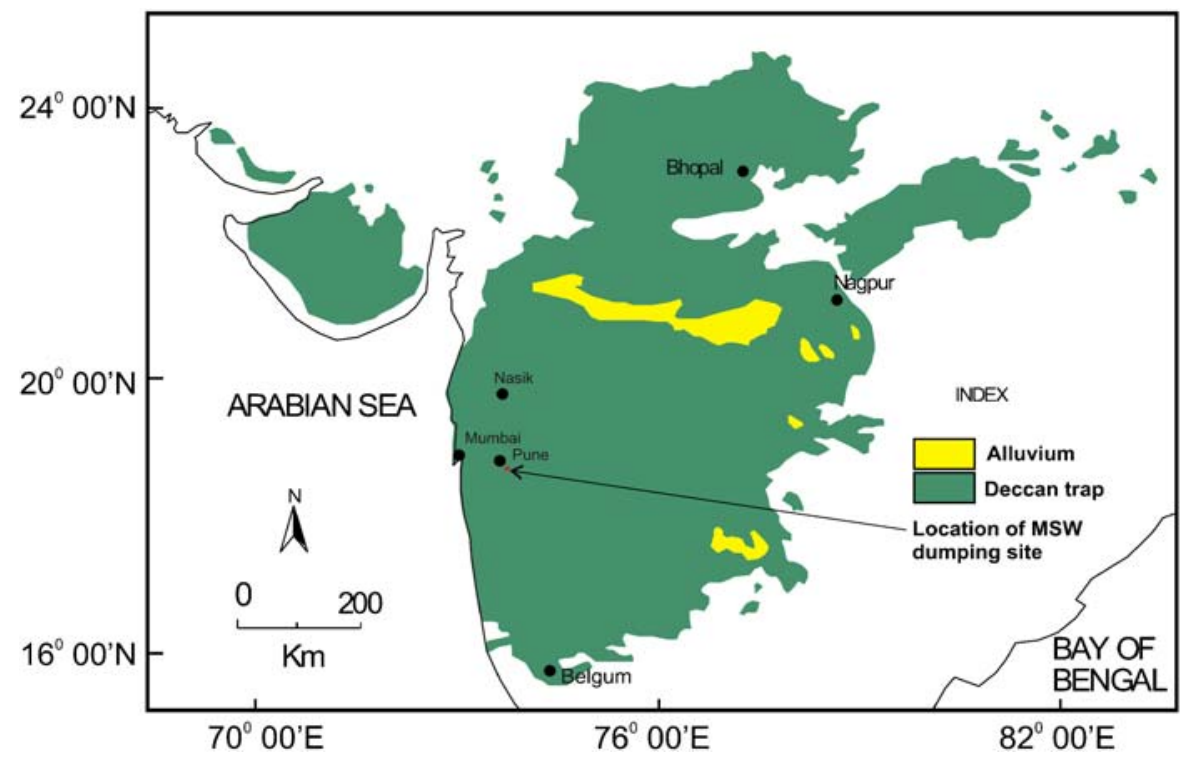

(Fig. 3). A substantial part of leachates derived from the municipal garbage gets naturally collected in a nearby small abandoned quarry (L7, Fig. 3) and acts as another point source. The total area available for MSW dumping site is about 163 acre, and total study area under investigation is $96 \mathrm{~km}^{2}$.

Dug wells are the principle source of water supply for drinking and other purposes in the study area. Groundwater withdrawal is confined to vesicular, weathered, jointed, and fractured upper basaltic crust, which is overlain by thin soil cover. Depleting groundwater levels are common, the condition being further aggravated by frequent drought like situations. Average groundwater level during pre-monsoon is $5.7 \mathrm{~m}$, whereas the water tables are fairly shallower during postmonsoon with an average depth of $2.7 \mathrm{~m}$. The erratic nature of southwest monsoon is the controlling factor for groundwater fluctuations. The effect of leachate percolation is observed in many nearby dug wells in the form of brown tainted waters with unpleasant foul smell.

The reddish brown soils rich in iron and ferric oxide content are present in higher regions of the study area (around the dumping site). These are medium textured silty soils. Moderately thick black soils rich in organic matter and humus content are observed in lower reaches. These are highly fertile and are under intensive irrigation.
Sporadic patches of grayish soils are developed along the gentle slopes. These are rich in $\mathrm{CaCO}_{3}$ and are described as calcareous soils.

\section{Materials and methods}

Sampling of leachate and groundwater

In order to observe the spatio-temporal variations in the geochemistry of leachates and groundwaters, two undiluted representative leachate samples (one from leachate collection pond 'L7' and another from the base of solid waste heap 'L5') and 19 groundwater samples (17 dug well, one bore well, and one surface water) were collected during November 2006 (post-monsoon) and May 2007 (pre-monsoon). A random sampling method was employed to collect the groundwater samples with due consideration to represent land-use patterns, topography, and areas close to dumping site. The samples were collected in pre-cleaned polyethylene container of 1-l capacity. The $\mathrm{pH}$ and EC were recorded on site at the time of sampling with digital $\mathrm{pH}$ meter and digital EC meter, respectively. For the analysis of biological oxygen demand (BOD), $300 \mathrm{ml}$ capacity BOD bottles were used for the collection of samples, and dissolved oxygen was fixed onsite. For heavy metal analyses, samples were separately collected 


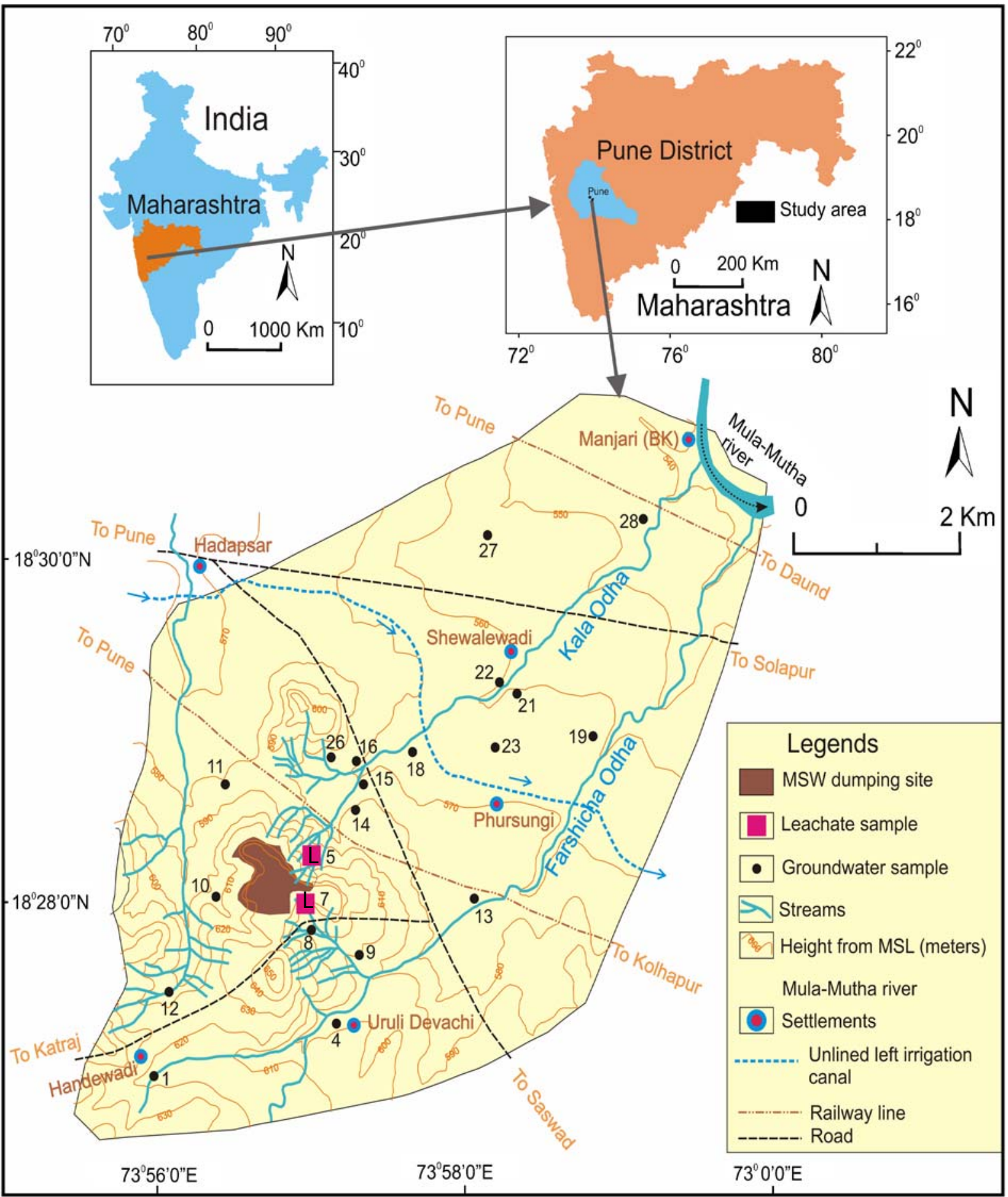

Fig. 3 Location map of the study area 
in pre-washed polyethylene containers of $100 \mathrm{ml}$ capacity and acidified onsite to avoid precipitation of metals. A Garmin global positioning system was used for recording spatial data.

Analytical methods

After sampling, the collected samples were immediately brought to the laboratory and kept in refrigerator at temperature below $4^{\circ} \mathrm{C}$ until analyzed (APHA 1995). The total hardness (TH), $\mathrm{Ca}, \mathrm{Mg}, \mathrm{HCO}_{3}^{-}$, and $\mathrm{Cl}^{-}$were analyzed by titrimetric methods (APHA 1995). The $\mathrm{Na}$ and $\mathrm{K}$ concentrations were determined by flame photometric method while $\mathrm{SO}_{4}^{2-}, \mathrm{PO}_{4}^{3-}$, and $\mathrm{NO}_{3}^{-}$were analyzed by using UV-VIS spectrophotometer. The chemical oxygen demand (COD) was determined by open reflux digestion method, and BOD was estimated by Azide modification of Winkler method. Total organic carbon (TOC), $\mathrm{F}^{-}$, and $\mathrm{CN}^{-}$were determined by a nano-colorimeter (500D). The trace element concentrations (Fe, $\mathrm{Zn}, \mathrm{Cu}, \mathrm{Ni}, \mathrm{Cd}, \mathrm{Pb}, \mathrm{Cr}, \mathrm{Mn}, \mathrm{Al}$, and $\mathrm{Co}$ ) were also determined by using a nano-colorimeter (500D).

While the groundwater in DVP is of $\mathrm{Ca}+$ $\mathrm{Mg}-\mathrm{HCO}_{3}$ type (Pawar et al. 1982), the monsoon rainwater is charged with chloride, sulfate, nitrate, sodium, calcium, magnesium, and negligible amounts of bicarbonates (Das et al. 2004). The rainwater inputs to the groundwater were deducted from the geochemical data obtained, and corrected records were used for the plots. Analytical precision of the major ionic constituents was measured by the normalized inorganic charge balance (Huh and Edmond 1999). The resulting cation-anion charge balance errors in all groundwater samples are within $\pm 5 \%$, which is considered to be acceptable (Berner-Kay and Berner 1987; Edmond et al. 1995; Huh and Edmond 1999).

\section{Results}

Geochemistry of "typical" groundwater from basaltic aquifer

There is fairly a good amount of information available on background chemistry of groundwa- ter from uncontaminated basaltic aquifers (Pawar and Shaikh 1995; Pawar et al. 2008). However, specifically, the studies on the chemistry of groundwater from Pune area are carried out by Pawar et al. (1982). Their findings indicate that while the wells piercing through basaltic, weathered basaltic, and doleritic dyke aquifers exhibit $\mathrm{Ca}+\mathrm{Mg}-\mathrm{HCO}_{3}$ water type, the alluvial aquifers are dominantly characterized by $\mathrm{Ca}+\mathrm{Mg}+\mathrm{Na}-$ $\mathrm{HCO}_{3}$ type. The ionic load of the groundwater is dominantly derived from weathering of ferromagnesian silicates (olivine and augite) and plagioclase feldspar, besides some contribution from zeolites (Pawar et al. 2008). This information has been used in comparing the characteristics of groundwater modified by mixing of leachate derived from MSW in the study area.

Leachate characterization

The leachate characterization was carried out for two consecutive seasons (post- and pre-monsoon). Leachate samples were analyzed for 18 general parameters and ten heavy metals as discussed under different heads. Average leachate composition (of L5 and L7) and its seasonal variation are shown in Table 1.

The $\mathbf{p H}$ and $\mathbf{E C}$ The average $\mathrm{pH}$ varies from 8.33 to 7.62 during post- and pre-monsoon seasons, respectively. The average values for EC are considerably high ranging between 99,510 and $685,400 \mu \mathrm{S} / \mathrm{cm}$ during the two seasons, respectively. The extremely high values for EC are attributable to high levels of anions and cations. Feebly alkaline nature of leachate is an indicator of the mature stage of the dumping site (Jorstad et al. 2004)

BOD, COD, and TOC The high values for BOD and COD (Table 1) are indicative of high organic matter in the wastes. The ratio for 5-day $\mathrm{BOD} / \mathrm{COD}$ for pre-monsoon is 0.75 , and for postmonsoon, it is 0.6 . This indicates that majority of the organic compounds is biodegradable (Fatta et al. 1999). The high values for TOC during both seasons are mainly due to decomposed and undecomposed product of organic wastes. 
Table 1 Physico-chemical characteristics of leachate (average of L5 and L7)

\begin{tabular}{|c|c|c|c|}
\hline Constituents & $\begin{array}{l}\text { Post } \\
\text { monsoon }^{a} \\
\text { Nov } 2006 \\
\end{array}$ & $\begin{array}{l}\text { Pre } \\
\text { monsoon }^{a} \\
\text { May } 2007 \\
\end{array}$ & $\begin{array}{l}\text { Percent increase } \\
\text { or decrease in } \\
\text { concentration }\end{array}$ \\
\hline $\mathrm{pH}$ & 8.33 & 7.62 & -9.32 \\
\hline $\mathrm{EC}$ & 99,510 & 685,400 & 85.48 \\
\hline $\mathrm{BOD}_{5}$ & 4,122 & 6891 & 40.18 \\
\hline COD & 6,834 & 9200 & 25.72 \\
\hline TOC & 5,434 & 7000 & 22.37 \\
\hline $\mathrm{TN}$ & 262.5 & 312.5 & 16.00 \\
\hline $\mathrm{TH}$ & 2,200 & 1802 & -22.09 \\
\hline $\mathrm{Na}^{+}$ & 2,550 & 2424 & -5.20 \\
\hline $\mathrm{K}^{+}$ & 186.5 & 239.92 & 22.27 \\
\hline $\mathrm{Ca}^{++}$ & 340.5 & 439.79 & 22.58 \\
\hline $\mathrm{Mg}^{++}$ & 110.5 & 170.08 & 35.03 \\
\hline $\mathrm{Fe}$ & 78.75 & 125 & 37.00 \\
\hline $\mathrm{F}^{-}$ & 21.37 & 29.25 & 26.94 \\
\hline $\mathrm{Cl}^{-}$ & 4,485 & 4764 & 5.86 \\
\hline $\mathrm{CN}^{-}$ & 0.19 & 0.27 & 29.63 \\
\hline $\mathrm{HCO}_{3}^{-}$ & 2170 & 5,000 & 56.60 \\
\hline $\mathrm{SO}_{4}^{2-}$ & 796 & 1024 & 22.27 \\
\hline $\mathrm{PO}_{4}^{3-}$ & 188.6 & 312.5 & 39.65 \\
\hline $\mathrm{NO}_{3}^{-}$ & 115 & 55 & -109.09 \\
\hline $\mathrm{Cd}$ & 0.93 & 1.24 & 25.00 \\
\hline $\mathrm{Cr}$ & 2.87 & 5.22 & 45.02 \\
\hline $\mathrm{Cu}$ & 0.9 & 1.47 & 38.78 \\
\hline $\mathrm{Mn}$ & 4.15 & 6.84 & 39.33 \\
\hline Co & 0.258 & 0.339 & 23.89 \\
\hline $\mathrm{Ni}$ & 2.05 & 2.72 & 24.63 \\
\hline $\mathrm{Pb}$ & 0.84 & 0.8 & -5.00 \\
\hline $\mathrm{Zn}$ & 1.63 & 1.91 & 14.66 \\
\hline $\mathrm{Al}$ & 7.46 & 11.12 & 32.91 \\
\hline $\mathrm{BOD}_{5} / \mathrm{COD}$ & 0.6 & 0.75 & 20.00 \\
\hline
\end{tabular}

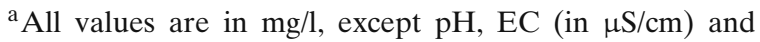
$\mathrm{BOD}_{5} / \mathrm{COD}$

Cations The possible sources of cations (Table 1) are domestic wastes. These values are higher than those mentioned for dumping sites operating for more than 10 years (Papadopoulou et al. 2007). Almost all cations show higher concentrations during pre-monsoon possibly due to higher evaporation effect under semi-arid climatic setup.

Anions The high amount of chloride (Table 1) in leachate is due to mixing of domestic waste (Mor et al. 2006). The possible anthropogenic sources of chloride are kitchen wastes from households, restaurants, and hotels. Elevated concentration of dissolved organic materials, such as leachate and ionically charged organic acids, could contribute significantly to the total alkalinity (Jorstad et al. 2004). Higher sulfate, nitrate, and fluoride concentrations (Table 1) are primarily due to domestic wastes. The total nitrogen (TN) having values of $262.5 \mathrm{mg} / \mathrm{l}$ (post-monsoon) and $312.5 \mathrm{mg} / 1$ (premonsoon) are toward the higher side because organic matter decomposition processes produce tremendous amount of ammonia. The cyanide concentration in leachate is low for both the seasons because of the absence of industrial wastes in the constituents of MSW. The higher values of phosphate (Table 1) also suggest a mature stage of the dumping site (Fatta et al. 1999).

Heavy metals The heavy metals analyzed are Al, $\mathrm{Cd}, \mathrm{Cr}, \mathrm{Cu}, \mathrm{Co}, \mathrm{Fe}, \mathrm{Mn}, \mathrm{Ni}, \mathrm{Pb}$, and $\mathrm{Zn}$ (Table 1). High concentration of $\mathrm{Cd}, \mathrm{Pb}, \mathrm{Ni}$, and $\mathrm{Zn}$ suggest that the wastes are mainly of municipal origin containing refused batteries, paint products, metallic items, and fluorescents lamps. Concentrations of $\mathrm{Cr}$ reveal the presence of wood preservatives and paint products in the waste, whereas high $\mathrm{Mn}$ concentrations suggest a strong reducing environment. The $\mathrm{Al}$ concentrations are a result of electronic wastes and aluminum foils. The high range of iron (Table 1) is an indicative of the dumping of metal scrap and tin-based garbage at the dumping site. The dark brown color of the leachate is attributable to the oxidation of ferrous to ferric form and the formation of ferric hydroxide colloids and complexes with fulvic and humic substances (Chu and Cheung 1994).

\section{Leachate pollution index}

The leachate pollution index (LPI) provides an efficient method for evaluating the leachate contamination potential. It serves as a vital tool for policy makers and public about pollution threat from landfill. It is a quantitative and comparative measure for the leachate pollution potential. The LPI is calculated using the equation (Kumar and Alappat 2005):

$\mathrm{LPI}=\sum_{i=1}^{n} W_{i} p_{i}$ 
where LPI $=$ the weighted additive LPI, $W_{i}=$ the weight for the $i$ th pollutant variable, $p_{i}=$ the subindex score of the $i$ th leachate pollutant variable, $n=$ number of leachate pollutant variables used in calculating LPI

and $\sum_{i=1}^{n} W_{i}=1$

However, when the data for all the leachate pollutant variables included in LPI are not available, the LPI can be calculated using the concentration of the available leachate pollutants. In that case, the LPI can be calculated by the equation:

$\mathrm{LPI}=\frac{\sum_{i=1}^{m} W_{i} p_{i}}{\sum_{i=1}^{m} W_{i}}$

where $m$ is the number of leachate pollutant parameters for which data are available, but in that case, $m<18$ and $\sum_{i=1}^{m} W_{i}<1$

The calculated LPI values at the site under review (Table 2) are comparable to those at various dumping sites in other metropolitan cities across the world (Kumar and Alappat 2005). Moreover, the present study takes into account the seasonal variation in the pollution potential of leachates. The lower LPI values for postmonsoon (19.04) than for pre-monsoon (24.67) suggest that the leachates have more polluting potential during pre-monsoon. This is evidenced in the highly deteriorated groundwater quality during pre-monsoon, as discussed in the next section. The high values of LPI during both the seasons demand that leachate generated from MSW dumping site should be treated, and site should be monitored on a continuous basis.

\section{Groundwater quality}

The groundwater in study area is mainly used for drinking and irrigation purpose. Tables 3 (postmonsoon 2006) and 4 (pre-monsoon 2007) depict the seasonal variation in the different parameters of groundwater in the study area. It is evident from the tables that the wells in the close vicinity of dumping site $(8,9,1314,15,16,18$, and 26) are the worst affected due to leachate percolation despite a less permeable basaltic terrain.

\section{Physico-chemical properties of groundwater}

The $\mathrm{pH}$ values (Table 3, physico-chemical data) for all groundwater samples are within the range

Table 2 LPI for pre-monsoon (Nov 2006) and post monsoon (May 2007) seasons

\begin{tabular}{|c|c|c|c|c|c|c|c|c|c|}
\hline \multirow[t]{2}{*}{ S. no } & \multirow[t]{2}{*}{$\begin{array}{l}\text { Leachate } \\
\text { constituent }\end{array}$} & \multicolumn{2}{|c|}{ Mean value } & \multicolumn{2}{|c|}{$\begin{array}{l}\text { Individual pollution } \\
\text { rating pi }\end{array}$} & \multicolumn{2}{|l|}{ Weight $W_{i}$} & \multicolumn{2}{|c|}{$\begin{array}{l}\text { Overall pollution } \\
\text { rating } p_{i} w_{i}\end{array}$} \\
\hline & & $\begin{array}{l}\text { Post } \\
\text { monsoon }\end{array}$ & $\begin{array}{l}\text { Pre } \\
\text { monsoon }\end{array}$ & $\begin{array}{l}\text { Post } \\
\text { monsoon }\end{array}$ & $\begin{array}{l}\text { Pre } \\
\text { monsoon }\end{array}$ & $\begin{array}{l}\text { Post } \\
\text { monsoon }\end{array}$ & $\begin{array}{l}\text { Pre } \\
\text { monsoon }\end{array}$ & $\begin{array}{l}\text { Post } \\
\text { monsoon }\end{array}$ & $\begin{array}{l}\text { Pre } \\
\text { monsoon }\end{array}$ \\
\hline 1 & $\mathrm{pH}$ & 8.33 & 7.62 & 5 & 5 & 0.055 & 0.055 & 0.275 & 0.275 \\
\hline 2 & TDS & 11,800 & 16,700 & 26 & 42 & 0.05 & 0.05 & 1.3 & 2.1 \\
\hline 3 & BOD5 & 4,122 & $6,891.5$ & 48 & 55 & 0.061 & 0.061 & 2.928 & 3.355 \\
\hline 4 & COD & 6,834 & 9,200 & 65 & 74 & 0.062 & 0.062 & 4.03 & 4.588 \\
\hline 5 & TKN & 262.5 & 312.5 & 7 & 8 & 0.053 & 0.053 & 0.371 & 0.424 \\
\hline 6 & Total iron & 78.75 & 125 & 8 & 11 & 0.045 & 0.045 & 0.36 & 0.495 \\
\hline 7 & Copper & 0.9 & 1.47 & 6 & 7 & 0.05 & 0.05 & 0.3 & 0.35 \\
\hline 8 & Nickel & 2.05 & 2.72 & 7 & 10 & 0.052 & 0.052 & 0.364 & 0.52 \\
\hline 9 & Zinc & 1.63 & 1.91 & 6 & 6 & 0.056 & 0.056 & 0.336 & 0.336 \\
\hline 10 & Lead & 0.84 & 0.8 & 7 & 7 & 0.063 & 0.063 & 0.441 & 0.441 \\
\hline 11 & Total chromium & 2.87 & 5.22 & 13 & 36 & 0.064 & 0.064 & 0.832 & 2.304 \\
\hline 12 & Chloride & 4485.23 & 4764.2 & 38 & 46 & 0.048 & 0.048 & 1.824 & 2.208 \\
\hline \multirow[t]{3}{*}{13} & Cyanide & 0.19 & 0.27 & 5 & 5 & 0.058 & 0.058 & 0.29 & 0.29 \\
\hline & Total & & & & & 0.717 & 0.717 & 13.651 & 17.686 \\
\hline & \multicolumn{7}{|c|}{ Final LPI value by dividing Total Overall pollution rating by total $W_{i}$} & 19.04 & 24.67 \\
\hline
\end{tabular}




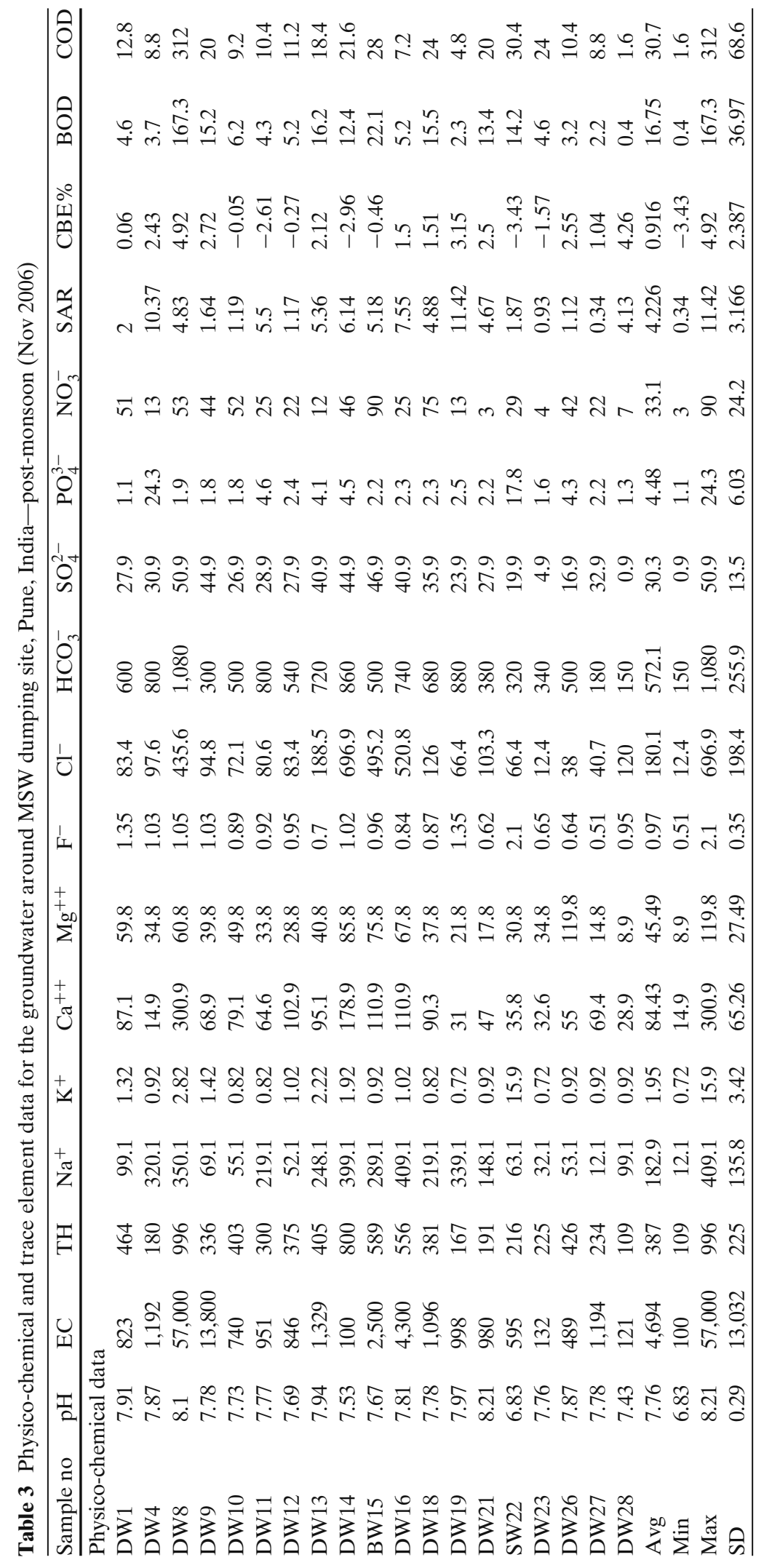




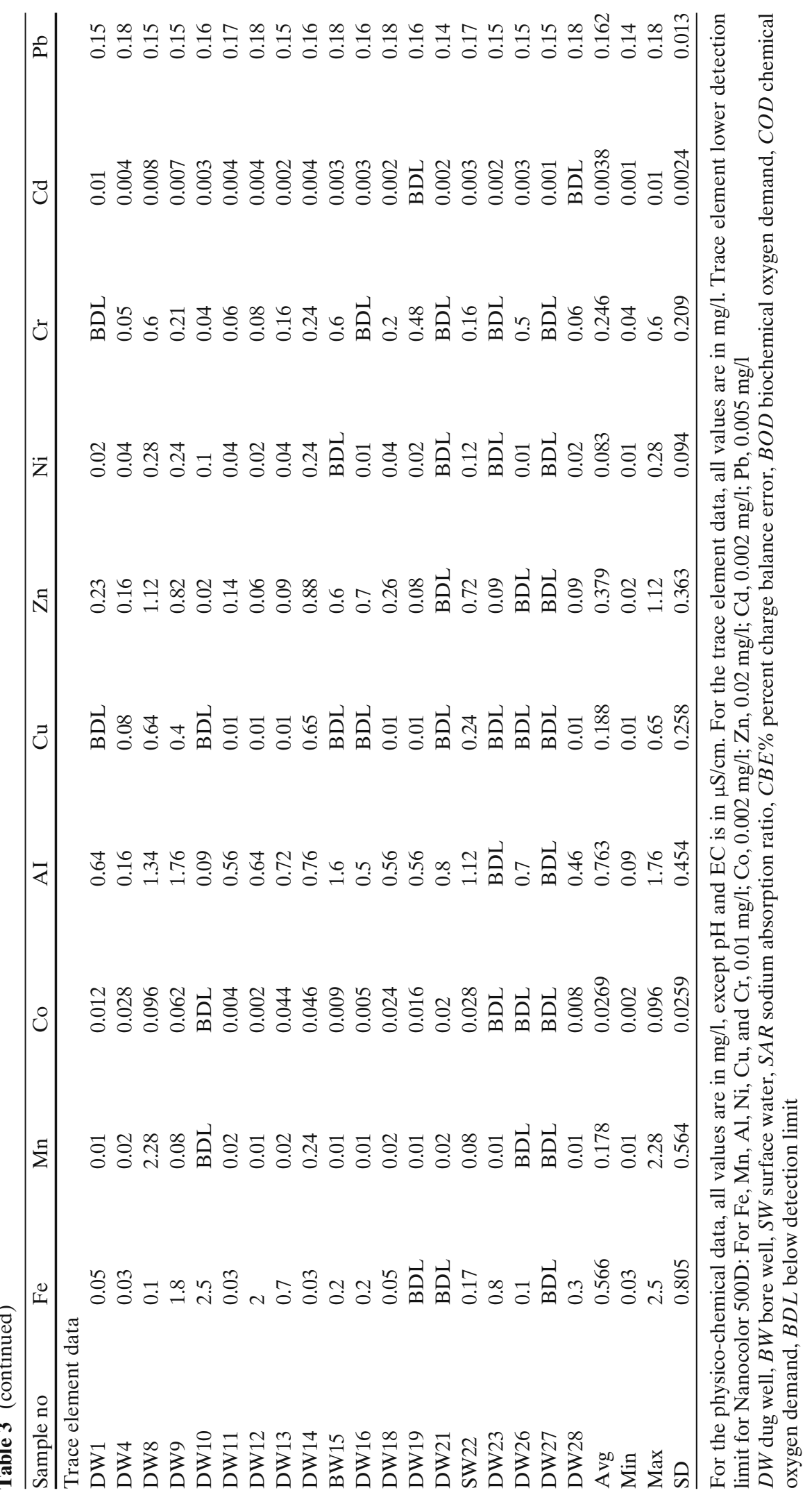




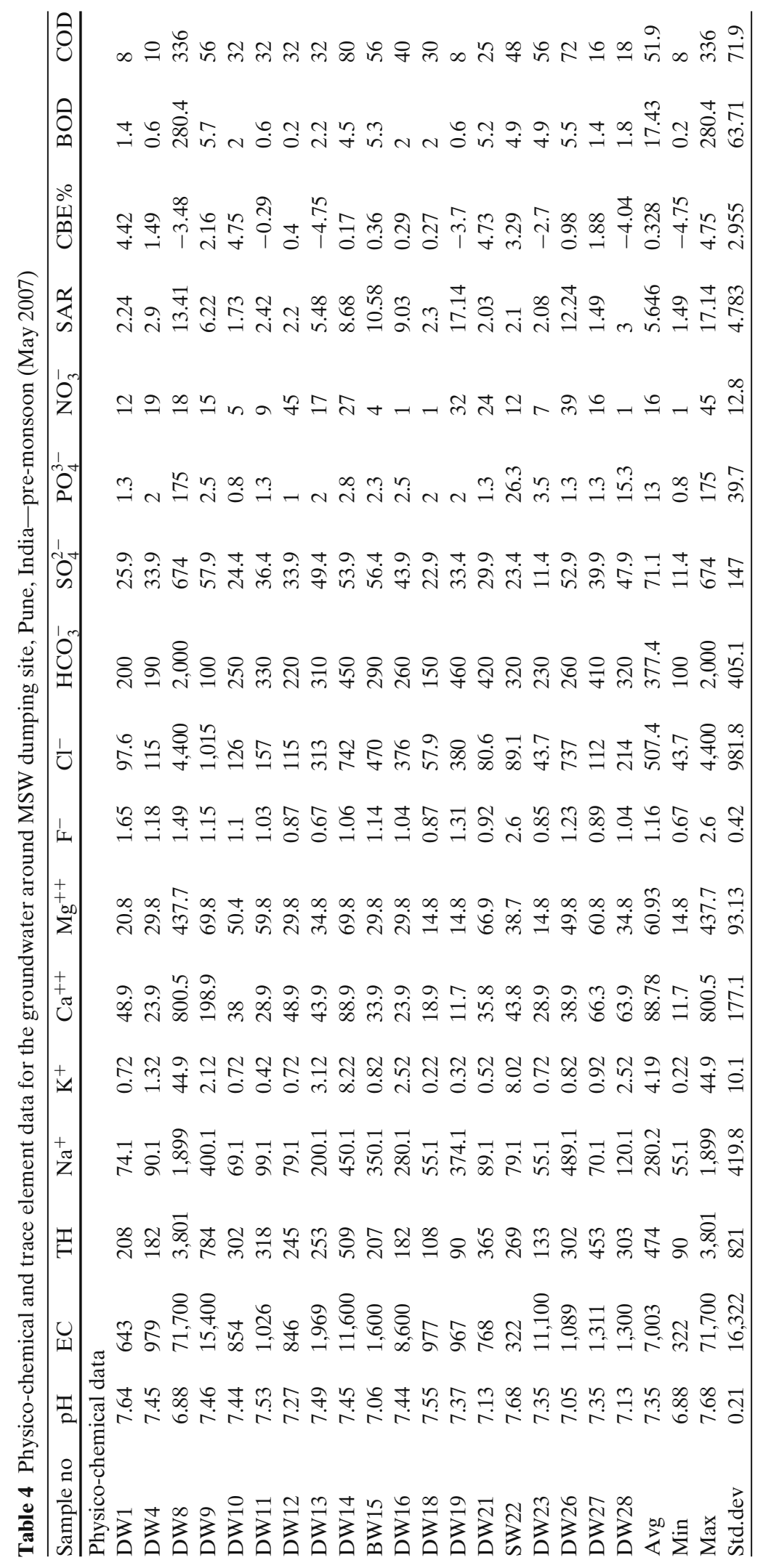




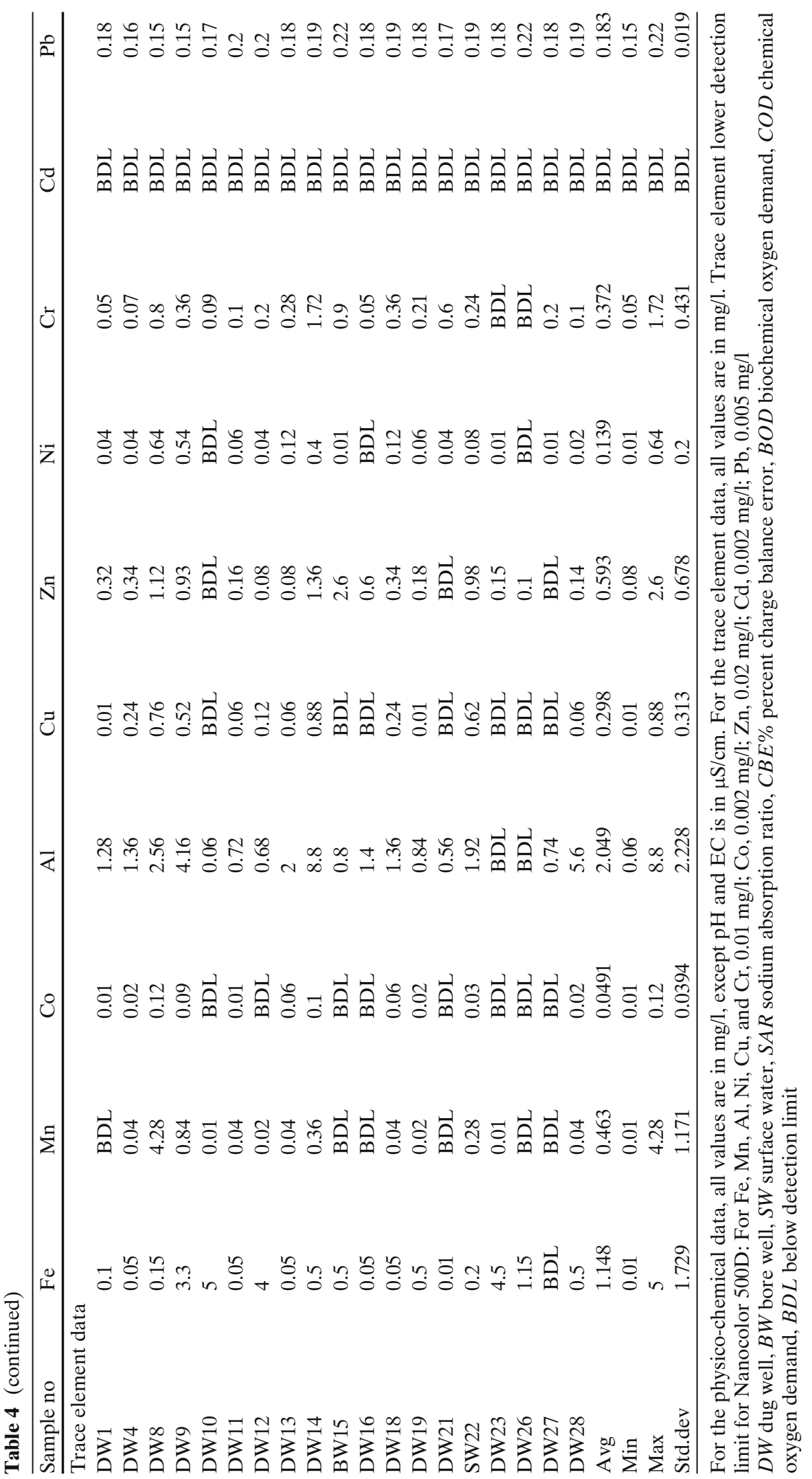


of WHO (2002) standards. EC is the indicator of dissolved inorganic ions in groundwater; the wells having highest values (DW8, DW9, and DW16) during both the seasons are in the close vicinity of dumping site demonstrating the effect of leachate on groundwater. Higher EC values during premonsoon possibly show the effect of evaporation as well as the impact of leachate. The BOD and COD values are relatively low for both seasons; yet, the wells around dumping sites have higher values (Table 3, physico-chemical data; highest values in DW 8 close to dumping site). The same is true for $\mathrm{TH}$ values.

\section{Major cations in groundwater}

Similar to physicochemical parameters discussed above, all wells around the dumping site exhibit
Fig. 4 a Scatter plot $\mathrm{Ca}+\mathrm{Na}$ vs $\mathrm{HCO} 3$. b Scatter plot $\mathrm{Mg}$ vs $\mathrm{HCO}_{3}$. c Scatter plot $\mathrm{Ca}+\mathrm{Mg}$ vs $\mathrm{HCO}_{3}$
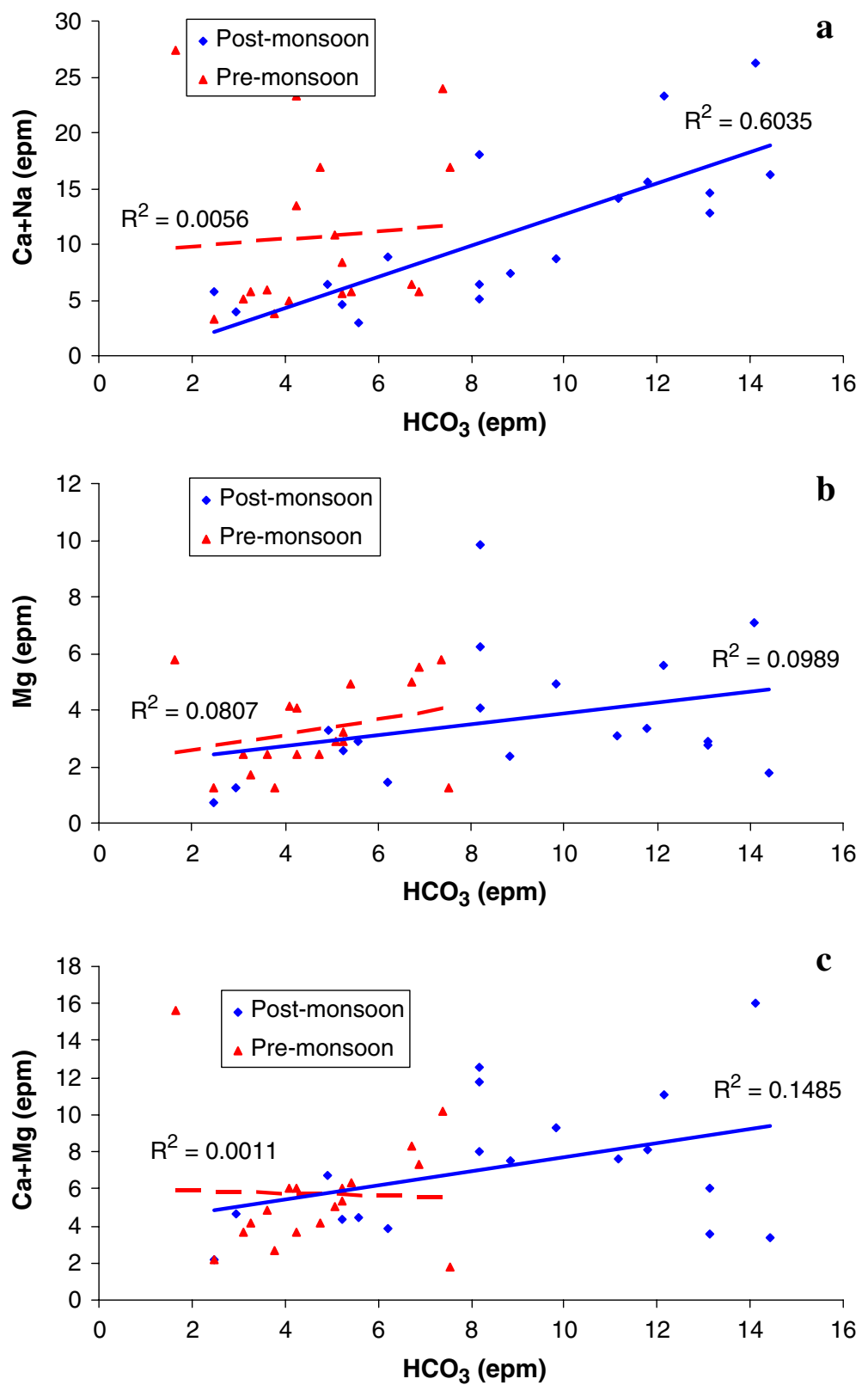
exceedingly higher values for major cations analyzed (Table 3, physico-chemical data), with DW8 showing highest values. The high concentration for sodium around the landfill indicates impact of leachate. The other cations also depict similar patterns. The high concentration of $\mathrm{Na}^{+}$may pose a risk to persons suffering from cardiac, renal, and circulatory diseases (Mor et al. 2006). Despite few inputs from agricultural activities, the high concentration of $\mathrm{K}^{+}$has been reported to be an indication of the leachate effect (Eillas 1980). Besides domestic wastes, the silicate minerals (plagioclase, feldspar, and augite) could also have contributed toward sources of sodium, calcium, and magnesium in basaltic host rock (Hem 1985).

\section{Major anions in groundwater}

An excess of chloride in water is usually taken as an index of pollution and considered as tracer for groundwater contamination (Loizidou and Kapetanios 1993). Higher concentrations of chlorides are observed in wells close to dumping site (DW8, DW9, DW14, and DW16) during both seasons. The concentration is considerably high in the well DW8; values ranged from $435.6 \mathrm{mg} / 1$ for postmonsoon to $4,400 \mathrm{mg} / \mathrm{l}$ for pre-monsoon. The high chloride content in groundwater is from pollution sources such as domestic effluents, fertilizers, septic tanks, and leachates (Mor et al. 2006). Increase in chloride level is injurious to people suffering from diseases of heart and kidney (WHO 2002). The high alkalinity imparts water an unpleasant taste and may be deleterious to human health along with the high $\mathrm{pH}$, TDS, and TH. Enhanced rock water interaction during post-monsoon could also contribute (to a limited extent) toward the increased values for $\mathrm{HCO}_{3}^{-}$(Pawar 1993).

Agricultural fertilizers and leachate are the main source of sulfate in groundwaters. The $\mathrm{SO}_{4}^{2-}$ concentration in groundwater is within WHO standard (2002) for both seasons. Still, the values are considerably high in DW8. The concentrations have reduced during post-monsoon possibly due to sulfate reduction. The agricultural fertilizers are also the main source of phosphate in groundwater. High concentration reduces the biotic component of groundwater. The highest concentrations are at DW8 during both the seasons, indicating the effect of leachate on groundwater. In general, the major sources for nitrate in groundwater include domestic sewage, runoff from agricultural fields, and leachate from landfill sites (Pawar and Shaikh 1995; Lee et al. 2003; Jalali 2005). Similar to other anions, the values for nitrate are higher in all the wells surrounding the dumping site. The decreasing hierarchy of dominant cations and anions in the groundwaters around the dumping site is $\mathrm{Na}^{+}>\mathrm{Ca}^{++}>$ $\mathrm{Mg}^{++}>\mathrm{K}^{+}$and $\mathrm{HCO}_{3}^{-}>\mathrm{Cl}^{-}>\mathrm{SO}_{4}^{2-}>\mathrm{NO}_{3}^{-}$. Except for few wells, the sodium absorption ratio values are low and have improved during postmonsoon season.

\section{Leachate as a source of ions in groundwaters}

Lithogenic inputs from rock-water interactions (dissolution of primary silicates) are the main sources of ions in groundwaters under natural conditions. The principal lithologic unit in the study area is basalt, which is distinguished by olivine (2-3\%), pyroxene (augite; $24-47 \%$ ), and plagioclase feldspar (labradorite; 40-65\%) (Bean et al. 1986; Subbarao et al. 1994). Incongruent dissolution of these primary silicate minerals in the groundwater can be given as follows (Pawar et al. 2008):

$$
\begin{gathered}
\mathrm{Mg}_{2} \mathrm{SiO}_{4}(\mathrm{~s})+4 \mathrm{H}_{2} \mathrm{CO}_{3}=2 \mathrm{Mg}+4 \mathrm{HCO}_{3}+\mathrm{H}_{4} \mathrm{SiO}_{4} \\
\text { Olivine } \\
{\left[m \mathrm{Mg} / m \mathrm{HCO}_{3}=1: 2\right]}
\end{gathered}
$$

$$
\begin{aligned}
& 4 \mathrm{Ca} 0.5 \mathrm{Na}_{0} .5 \mathrm{Al}_{2} \mathrm{Si}_{2} \mathrm{O}_{8}(\mathrm{~s})+6 \mathrm{CO}_{2}+9 \mathrm{H}_{2} \mathrm{O}=3 \mathrm{Al}_{2} \mathrm{Si}_{2} \mathrm{O}_{5}(\mathrm{OH})_{4}+2 \mathrm{Na}+2 \mathrm{Ca}+6 \mathrm{HCO}_{3}+4 \mathrm{SiO}_{2} \\
& \text { Plagioclase } \\
& {\left[m \mathrm{HCO}_{3} / m \mathrm{SiO}_{2}=3: 2 \text { and } m \mathrm{Na} / m \mathrm{Ca}=1: 1\right]}
\end{aligned}
$$




$$
\begin{aligned}
\mathrm{CaMgFeAl}_{2} \mathrm{Si}_{3} \mathrm{O}_{12}(\mathrm{~s})+6 \mathrm{CO}_{2}+5 \mathrm{H}_{2} \mathrm{O}= & \mathrm{Al}_{2} \mathrm{Si}_{2} \mathrm{O}_{5}(\mathrm{OH})_{4}+\mathrm{Ca}+\mathrm{Mg}+\mathrm{Fe}+6 \mathrm{HCO}_{3}+\mathrm{SiO}_{2} \\
\text { Augite } & {\left[m \mathrm{HCO}_{3} / m \mathrm{SiO}_{2}=6: 1 \text { and } m \mathrm{Ca} / m \mathrm{Mg}=1: 1\right] }
\end{aligned}
$$

Rainwater charged by $\mathrm{CO}_{2}$ in the atmosphere permeates through soil zone and stimulates the basaltic aquifers in the area, which is the source of protons in the above reactions. The above rockwater interaction processes liberate base cations (especially $\mathrm{Ca}, \mathrm{Mg}$, and $\mathrm{Na}$ ) and bicarbonate along with concurrent increase in $\mathrm{pH}$ (Rabemanana et al. 2005). Considering Eq. 2, plagioclase feldspar (labradorite) is a solid solution series between anorthite (An) and albite (Ab) in the basalt, which sets $\mathrm{Na} / \mathrm{Ca}$ ratio in the groundwater from 0.5 to 1.0 (Garrels 1967; Drever 1982). The attributes for $\mathrm{Na} / \mathrm{Ca}$ ratio (post-monsoon, 0.17-21.45, average 3.38; pre-monsoon, 1.06-31.86, average 5.51) in groundwaters from the study area are far beyond this range, signifying dominant influence of leachates on groundwaters. The values have improved during post-monsoon due to enhanced rock-water interactions as well as dilution of leachates. The increase in the values of $\mathrm{Na} / \mathrm{Ca}$ in some wells could also be due to the precipitation of secondary $\mathrm{CaCO}_{3}$ minerals in unsaturated zone. Field observations support this inference, as secondary carbonates are observed in the dug well sections of weathered basaltic aquifers. However, very low values of $\mathrm{Na} / \mathrm{Ca}(0.17)$ are observed in only one well (DW 27) far away from the landfill as well as the leachate carrying stream (Kala Odha).

The scatter plot $\mathrm{Na}+\mathrm{Ca}$ vs $\mathrm{HCO}_{3}$ (Fig. 4a) shows weak positive correlation both in post- and pre-monsoon seasons. This supports the meager input of these ions from plagioclase dissolution. The cross-plots of $\mathrm{Mg}$ vs $\mathrm{HCO}_{3}$ and $\mathrm{Ca}+\mathrm{Mg}$ vs $\mathrm{HCO}_{3}$ also depict poor correlation (Fig. 4b, c), suggesting scant contribution from olivine and pyroxene weathering $\left(\mathrm{Ca}+\mathrm{Mg}-\mathrm{HCO}_{3}\right)$. This implies that the major part of the ionic load in the groundwaters is dominantly derived from leachates. All correlations have slightly improved
Table 5 Groundwater samples exceeding permissible limits for trace elements (WHO 2002)

\begin{tabular}{llll}
\hline Element & $\begin{array}{l}\text { WHO permissible } \\
\text { limit }(\mathrm{mg} / \mathrm{l})\end{array}$ & $\begin{array}{l}\text { Post-monsoon } \\
(\%)\end{array}$ & $\begin{array}{l}\text { Pre-monsoon } \\
(\%)\end{array}$ \\
\hline $\mathrm{Fe}$ & 0.3 & 31.58 & 47.37 \\
$\mathrm{Mn}$ & 0.5 & 5.26 & 10.53 \\
$\mathrm{AI}$ & 0.2 & 78.95 & 84.21 \\
$\mathrm{Cu}$ & 1.0 & 0.00 & 0.00 \\
$\mathrm{Zn}$ & 5.0 & 0.00 & 0.00 \\
$\mathrm{Ni}$ & 0.02 & 68.42 & 68.42 \\
$\mathrm{Cr}$ & 0.05 & 68.42 & 89.47 \\
$\mathrm{Cd}$ & 0.003 & 63.15 & 0.00 \\
$\mathrm{~Pb}$ & 0.001 & 100 & 100 \\
\hline
\end{tabular}

during post-monsoon due to dilution of leachates and enhanced rock-water interactions. Availability of larger surface area during post-monsoon provides favorable conditions for the above geochemical reactions.

\section{Trace elements in groundwater}

Despite high concentration of almost all heavy metals analyzed in the leachates (Table 1), the groundwaters (Tables 3 and 4, trace element data) in the study area are least affected by the metal pollution except well numbers DW1 and DW11, where $\mathrm{Pb}$ and $\mathrm{Zn}$ values are elevated possibly due to localized sources of pollution such as agriculture. However (barring a few exceptions), heavy metal concentrations (except $\mathrm{Cu}$ and $\mathrm{Zn}$ ) in majority of groundwater samples are above permissible limits (WHO 2002; Table 5).

\section{Discussion}

The present results demonstrate the impact of leachate on deteriorating groundwater quality in a 
basaltic terrain. The leachates having moderately high pollution potential (LPI = 19.04 and 24.65 in post- and pre-monsoon, respectively) have largely modified the groundwater quality in terms of its physicochemical parameters. The wells in the close vicinity of the dumping site are the worst affected despite a hard, compact, and less permeable basaltic lithology. Various controlling factors for the leachate contamination are outlined below.

Rainfall parameter The rainfall pattern in the semi-arid regions of DVP is erratic. Long drought years and occasional heavy wet spells lead to accelerated dispersion of leachate in the surrounding areas causing surface and subsurface contamination. It is to be noticed that the year 2006 experienced heavy rainfall (more than two times of the annual average). The groundwater quality as well as leachate pollution potential is improved during post-monsoon plausibly due to heavy rainwater recharge.

Leachate transportation mode Two leachatereceiving modes in the aquifers of the area are identified. As the Kala Odha (Fig. 5b) originates near MSW site, it receives leachates directly from the base of dumping site that perennially flows through it. The width of this leachate-carrying channel is quite limited ( $2-5 \mathrm{ft})$; still, it acts as a linear source of pollution. On the contrary, the surface water flowing in Farshicha Odha is relatively unpolluted, and the channel is dry for most of the times. It is interesting to note that the wells situated along the Farshicha Odha are highly polluted (wells 9 and 13). This implies toward another mode of leachate movement through soilhard rock interface and also through weathered, fractured, jointed, and vesicular upper basaltic crust along the gentle slopes. This second mode is more dominant, as lateral recharge from polluted channels in hard rock is restricted. This is evidenced by the low pollution levels in wells 22 and 28 located at the banks of Kala Odha.

Topography Basaltic terrains exhibit undulatory and rugged topography. The location of dumping site near the top of a topographic high (recharge zone) has induced the permeation of leachate in the groundwater system along the slopes. The wells (DW1, DW10, DW11, and DW12) are practically unaffected by the leachate contamination because these wells lie on the opposite (western) slope of the topographic high (Fig. 3).

Redox controls Despite high concentration of heavy metals in the leachate, the groundwaters exhibit feeble geochemical signatures in terms of heavy metal contents. Even the wells in the close vicinities of dumping site are least affected by the high-level presence of heavy metals in the leachates. This implies toward redox controls over occurrence and movement of trace elements. A reductive ambient subsurface environment is favorable for the concentration of heavy metals (particularly $\mathrm{Fe}, \mathrm{Mn}, \mathrm{Cu}, \mathrm{Pb}$, and $\mathrm{Zn}$ ) in the groundwater system (Edmunds et al. 2002; Pawar and Nikumbh 1999). It is to be noted that in basaltic terrains, the groundwater is confined to fractured, fissured, jointed, and weathered zones/pockets. Water table fluctuation in such a litho-environment is diminutive and heterogeneous. As a result, highly reducing conditions are generally not reached particularly under sloping conditions. Moreover, the heavy metals remain in the waste or at the waste-rock interface as a result of redox-controlled precipitation reactions (Yanful et al. 1988). The metal mobility is also controlled by physical sorptive mechanisms, and landfills have an inherent in situ capacity for minimizing the mobility of heavy metals (Pohland et al. 1993). These conditions have moderately retarded the permeation of heavy metals into the groundwater system.

Influence of unlined irrigation canal An unlined NW-SE running canal flows across the regional slopes and groundwater flow in the area. This has moderately retarded the permeation of contaminants in areas down-slope side of the canal, as evidenced by low contamination levels in wells DW19, DW21, SW22, DW23, DW27, and DW28.

Age of MSW dumping site The dumping site has been receiving solid wastes without proper segregation and pretreatment since 1993. Millions of tons of solid wastes have already been dumped at the site. Age of the landfill dominantly governs 

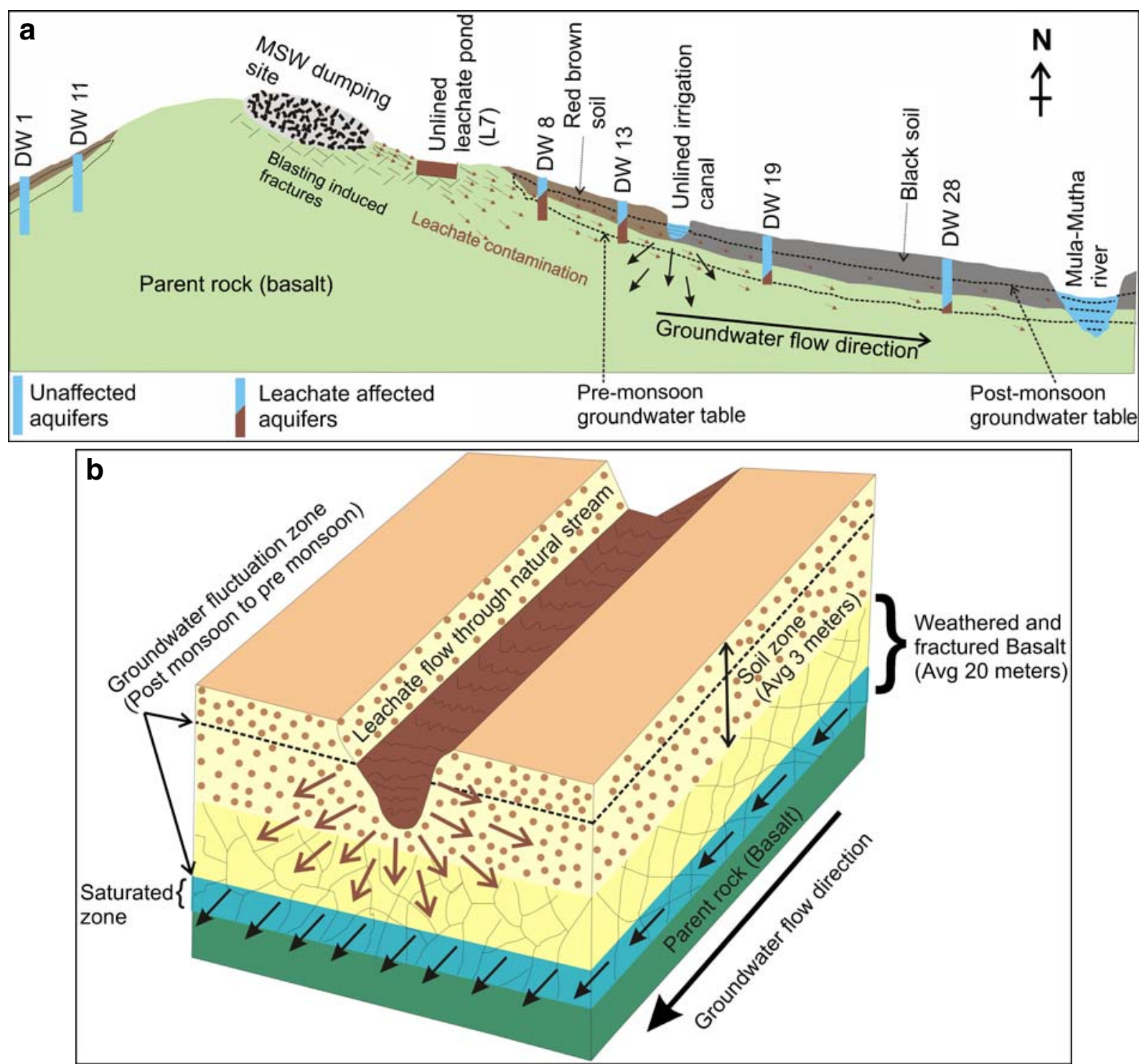

Fig. 5 a Conceptual model depicting dispersion of leachate contaminants in the groundwaters. b Model depicting mode of transport of leachate contaminants in the groundwaters

the leachate characteristics and hence influences the LPI values. High LPI values indicate that the leachates generated from the dumping site are not stabilized. This has resulted in high concentrations of heavy metals in leachate.

Induced fracturing The dumping site was previously an abandoned stone quarry before 1993 . The building stone excavations in the region generally go up to a depth of $40 \mathrm{~m}$. Quarrying of hard and compact basaltic materials needs a large-scale blasting that generates induced fracturing in the surrounding host rocks. These induced fractures in the country rocks at the dumping site have accelerated the subsurface permeation of leachates to the surrounding wells.

Surface and subsurface flow dynamics The occasional, short-spelled, and heavy rains generate intense sheet flows along the gentle slopes in the 
region. As the location of dumping site is on the eastern slopes of the topographic high, heavy rains cause huge amount of leachate dispersal over the entire area toward NE of dumping site. This runoff water (sheet flow) looks dark black in color because of occasional burning (five to six times in a year) of solid wastes. It spreads over large areas including soil horizons eventually contaminating the open wells and natural streams.

Along the groundwater flow direction (towards $\mathrm{NE}$ ), the leachate contaminants travel through subsurface fractured and fissured upper basaltic crust to low-lying areas. The subsurface flow increases during post-monsoon season, though the leachates are diluted. The unlined canal cuts across the general slope and groundwater flow lines thereby reducing the dispersal of leachate contaminants in the down-slope areas.

A conceptual model depicting mechanisms of leachate contamination in the area is shown in Fig. 5a and b. The model is expected to be helpful in deciphering conducive and non-conducive areas for leachate migration and contamination.

\section{Remedial measures}

The 3-R principle (reduce, reuse, and recycle) is an appropriate methodology for solid waste management and also for abatement of leachateinduced groundwater pollution. Adopting decentralized dumping sites in million plus cities like Pune may reduce the amount of leachate generation and its pollution potential. Reduction of solid waste generation at source may be achieved by various awareness campaigns in residential societies. Proper segregation of biodegradable and non-biodegradable wastes at the source should be practiced with composting the daily solid waste generated at the vicinity of residential complexes (e.g., vermicomposting) and reuse-recycle of the non-biodegradable waste.

Construction of lined dumping site and leachate collection ponds positively helps avoid transport of leachate to subsurface aquatic environment. The proper physico-chemical treatments (coagulation, precipitation, ammonia stripping, activated carbon adsorption, ion exchange, and reverse osmosis) could be applied to reduce the organic, inorganic, and heavy metal load through leachate (Chttaranjan and Chan 1986). Furthermore, biological treatment (aerobic/anaerobic) would be economical with methane gas generation and utilization.

\section{Conclusion}

The lateral and vertical flow of water in hard rock terrains like basalt is slow and unstable due to constricted passages. This, to a certain extent, restricts the migration of contaminants from source to receptors. However, a negative consequence of the mechanism is that the pollutants maintain a constant level of contamination and their toxicities. This is evidenced by the higher level of pollution in the wells adjoining the dumping site during both seasons despite rainwater recharge during monsoon.

The leachate derived from the Pune municipal waste dumping site demonstrates exceedingly high values for almost all physico-chemical parameters analyzed, including potentially toxic heavy metals. The influence of leachate percolation (through two different modes) is evident on the surrounding wells. Besides meager lithogenic inputs from rock-water interactions in basaltic litho-environment, the leachates are the prime source of all ions in the groundwater. High LPI values indicate that the leachates generated from dumping site are not stabilized, resulting in high concentrations of heavy metals in leachate. Despite their high concentrations, the groundwaters are least affected in terms of heavy metal contents, plausibly due to redox controls. Various geoenvironmental features like topography, relief, and flow dynamics have largely controlled the permeation of leachate to the groundwater system in the basaltic terrain under semi-arid climatic regime. Erratic rainfall patterns and induced fracturing in the country rocks have accelerated the contaminant movement and infiltration. Although the intensity of pollution in the groundwaters can be mitigated by the remedial measures discussed, the present study warrants for a proper solid waste management as a long-term policy in metropolitan cities. 
Acknowledgements Authors would like to thank Prof. V. S. Ghole, Head, Department of Environmental Sciences, and Head, Department of Geology University of Pune, for providing necessary facilities. Thanks are due to Prof. P.G. Saptarshi, (Department of Environmental Sciences) for continuous encouragement and support. Help in fieldwork and analyses of samples by Mr. S. K. Gaikwad and Mr. S. D. Kodre is thankfully acknowledged.

Open Access This article is distributed under the terms of the Creative Commons Attribution Noncommercial License which permits any noncommercial use, distribution, and reproduction in any medium, provided the original author(s) and source are credited.

\section{References}

APHA.AWWA, WPCF (1995). Standard methods for the examination water and wastewater (17th ed.). Washington DC, USA: APHA.AWWA, WPCF.

Bean, J. E., Turner, C. A., Hooper, P. R., Subbarao, K. V., \& Walsh, J. N. (1986). Stratigraphy, composition and form of Deccan Basalts, Western Ghats, India. Bulletin of Volcanology, 48, 61-83. doi:10.1007/ BF01073513.

Berner-Kay, E., \& Berner, R. A. (1987). The global water cycle, geochemistry and environment. Englewood Cliffs: Prentice-Hall.

Chttaranjan, R., \& Chan, P. C. (1986). Heavy metals in landfill leachate. The International Journal of Environmental Studies, 27, 225-237.

Chu, L. M., \& Cheung, K. C. (1994). Variations in the chemical properties of landfill leachate. Environmental Management, 18, 105-117. doi:10.1007/ BF02393753.

Das, A., Krishnaswami, S., Sarin, M. M., \& Pande, K. (2004). Chemical weathering in the Krishna Basin and Western Ghats of the Deccan Traps, India: Rates of basalt weathering and their controls. Geochimica et Cosmochimica Acta, 69(8), 2067-2084. doi:10. 1016/j.gca.2004.10.014.

Drever, J. I. (1982). The geochemistry of natural waters. New York: Prentice Hall.

Edmond, J. M., Palmer, M. R., Measures, C. R., Grant, B., \& Stallard, R. F. (1995). The fluvial geochemistry and denudation rate of the Guayana Shield in Venezuela. Geochimica et Cosmochimica Acta, 59, 3301-3323. doi:10.1016/0016-7037(95)00128-M.

Edmunds, W. M., Carrillo-Rivera, J. J., \& Cardona, A. (2002). Geochemical evolution of groundwater beneath Mexico City. Journal of Hydrology (Amsterdam), 258, 1-24. doi:10.1016/S0022-1694(01) 00461-9.

Eillas, J. A. (1980). Convenient parameter for tracing leachate from sanitary landfills. Water Research, 14, 1283-1287. doi:10.1016/0043-1354(80)90187-6.
Environmental Status Report (ESR) (2006). Pune municipal corporation (pp. 12.1-12.12).

Fatta, D., Papadopoulos, A., \& Loizidou, M. (1999). A study on the landfill leachate and its impact on the groundwater quality of the greater area. Environmental Geochemistry and Health, 21(2), 175190. doi:10.1023/A:1006613530137.

Garrels, R. M. (1967). Genesis of some groundwater from igneous rocks. In P. H. Abelson (Ed.), Researches in geochemistry (Vol. 2, pp. 405-420). New York: Wiley.

Hem, J. D. (1985). Study and interpretation of the chemical characteristics of natural water. USGS water supply paper 2254.

Huh, Y., \& Edmond, J. M. (1999). The fluvial geochemistry of the rivers of eastern Siberia: III, tributaries of the Lena and Anabar draining the basement terrain of the Siberian Craton and the Trans-Baikal highlands. Geochimica et Cosmochimica Acta, 63, 967-987. doi:10.1016/S0016-7037(99)00045-9.

Indian Meteorological Department (IMD) (2007). Pune weather station report.

Jalali, M. (2005). Nitrate leaching from agricultural land in Hamadan, western Iran. Agriculture Ecosystems \& Environment, 110, 210-218. doi:10.1016/j.agee.2005.04.011.

Jorstad, L. B., Jankowski, J., \& Acworth, R. I. (2004). Analysis of the distribution of inorganic constituents in a landfill leachate contaminated aquifers Astrolabe Park, Sydney, Australia. Environmental Geology, 46, 263-272. doi:10.1007/s00254-004-0978-3.

Krishnan, M. S. (1982). Geology of India and Burma (6th ed.). New Delhi: CBS.

Kumar, D., \& Alappat, B. J. (2005). Evaluating leachate contamination potential of landfill sites using leachate pollution Index. Clean Technologies and Environmental Policy, 7, 190-197. doi:10.1007/s10098-004-0269-4.

Lee, S. M., Min, K. D., Woo, N. C., Kim, Y. J., \& Ahn, C. H. (2003). Statistical assessment of nitrate contamination in urban groundwater using GIS. Environmental Geology, 44, 210-221.

Loizidou, M., \& Kapetanios, E. G. (1993). Effect of leachate from landfills on underground water quality. The Science of the Total Environment, 128, 69-81. doi:10.1016/0048-9697(93)90180-E.

Mor, S., Ravindra, K., Dahiya, R. P., \& Chandra, A. (2006). Leachate characterization and assessment of groundwater pollution near municipal solid waste landfill site. Environmental Monitoring and Assessment, 118, 435456. doi:10.1007/s10661-006-1505-7.

Papadopoulou, M. P., Karatzas, G. P., \& Bougioukou, G. G. (2007). Numerical modeling of the environmental impact of landfill leachate leakage on ground water quality-a field application. Environmental Modeling and Assessment, 12, 43-54. doi:10.1007/ s10666-006-9050-x.

Pawar, N. J. (1993). Geochemistry of carbonate precipitation from the ground waters in basaltic aquifers: An equilibrium thermodynamic approach. Journal of the Geological Society of India, 41, 119-131.

Pawar, N. J., \& Shaikh, I. J. (1995). Nitrate pollution of groundwaters from shallow basaltic aquifers, Deccan 
trap hydrologic province, India. Environmental Geology, 25, 197-204. doi:10.1007/BF00768549.

Pawar, N. J., \& Nikumbh, J. D. (1999). Trace element geochemistry of groundwater from Behedi basin, Nasik district, Maharashtra. Journal of the Geological Society of India, 54, 501-514.

Pawar, N. J., Thigale, S. S., \& Powar, K. B. (1982). Chemsitry of groundwaters from Pune area, Maharashtra. In Proc. int. symp. hydrological aspects of mountainous watersheds, Roorkee (Vol. I, pp. X1-X6).

Pawar, N. J., Pawar, J. B., Suyash, K., \& Ashwini, S. (2008). Geochemical eccentricity of ground water allied to weathering of basalt from the Deccan volcanic province, India: Insinuation on $\mathrm{CO}_{2}$ consumption. Aquatic Geochemistry, 14, 41-71. doi:10.1007/ s10498-007-9025-9.

Pohland, F. G., Cross, W. H., \& Gould, J. P. (1993). Metal speciation and mobility as influenced by landfill disposal practices. In H. E. Allen, E. M. Perdue, \& D. S. Brown (Eds.), Metals in groundwater (pp. 411429). Boca Raton: Lewis.
Rabemanana, V., Violette, S., de Marsily, G., Robain, H., Deffontaines, B., Andrieux, P., et al. (2005). Origin of the high variability of water mineral content in the bedrock aquifers of Southern Madagascar. Journal of Hydrology (Amsterdam), 310, 143-156. doi:10.1016/j.jhydrol.2004.11.025.

Subbarao, K. V., Chandrasekharam, D., Navaneethakrishanan, P., \& Hooper, P. R. (1994). Stratigraphy and structure of parts of the central Deccan Basalt Province: Eruptive models. In K. V. Subbarao (Ed.), Volcanism-Radhakishnna volume (pp. 321-332). New York: Wiley.

World Health Organization (WHO) (2002). Guideline for drinking water quality (2nd ed.). Health criteria and other supporting information (pp. 940-949). Geneva: World Health Organization.

Yanful, E. K., Quigley, R. M., \& Nesbitt, H. W. (1988). Heavy metal migration at a landfill site, Sarnia, Ontario, Canada-2: Metal partitioning and geotechnical implications. Applied Geochemistry, 3, 623-629. doi:10.1016/0883-2927(88)90094-7. 